\title{
REVITALISASI KIAS DALAM HUKUM PIDANA ISLAM
}

\author{
M. Nurul Irfan \\ UIN Syarif Hidayatullah Jakarta \\ Jl. Ir. H. Juanda No. 95 Ciputat Jakarta \\ Email:mnurulirfan@yahoo.com
}

\begin{abstract}
Abstrak
Dalam Hukum Pidana dikenal sebuah prinsip dasar dan sebagai asas terpenting yaitu asas legalitas. Di antara tiga pengertian dasar sebagai penjabaran dari asas legalitas di atas, bahwa untuk menentukan adanya perbuatan pidana tidak boleh digunakan analogi (kias). Kalau larangan penggunaan analogi atau kias dalam hukum pidana ini juga diberlakukan dalam hukum pidana Islam, tampaknya akan banyak menimbulkan persoalan, sebab kalau kias tidak berlaku, maka akan sangat banyak berbagai jenis jarimah atau tindak pidana yang tidak bisa ditetapkan sanksinya. Penyalahgunaan obat-obat terlarang dan berbagai kejahatan narkotika tidak bisa dihukum dengan berpijak pada ayat khamr, seorang koruptor tidak bisa dihukum potong tangan karena korupsi tidak bisa dikiaskan dengan pencurian yang sanksi hukumnya berupa potong tangan, illegal loging, women atau baby traficking, cyber crime dan beberapa jenis tindak pidana modern lain tidak bisa diproses secara hukum Islam. Tentu saja larangan penggunaan analogi atau kias dalam bidang hukum pidana Islam seyogyanya tidak disamakan dengan prinsip hukum pidana konvensional yang mengenal asas legalitas dengan kaedah turunannya berupa larangan kias atau analogi dalam hukum pidana.
\end{abstract}

Kata Kunci : Hukum Pidana Islam, kias, takzir, khamr, jarimah

\begin{abstract}
The most important basic principle in criminal law is legality principle. Among three basic interpretations of legality principle is that it is not legal using analogy to determine a criminal act. If the prohibition of using analogy in criminal law is also applied to Islamic criminal law, then it seems causing problems in the application of laws, because there are so many new types of criminal acts that need laws and sanctions. If analogy is not used in the Islamic criminal law, then drug abuses and many other drug crimes, for example, would not be punished based on khamr verses of the Qur'an; corruption and illegal logging could not be punished based on thieving law with chooping hand as its punishment; and so human trafficking, cyber crimes and many other modern criminal acts would not be punished based on Islamic criminal laws. Therefore, the prohibition of using analogy in Islamic criminal law should not be treated as that in conventional criminal law with its legality principle, which one of its interpretation is the prohibition of using analogy.
\end{abstract}

Keywords : Islamic criminal law, analogy, ta'zir, khamr, jarimah 


\section{A. Pendahuluan}

Kias merupakan suatu cara penggunaan ra'yu atau akal pikiran manusia untuk menggali hukum syara' dalam hal-hal yang naș al-Qur'an dan alsunnah tidak menetapkan hukumnya secara jelas. Pada dasarnya ada dua macam cara penggunaan ra'yu yaitu penggunaan ra'yu yang masih merujuk kepada naș dan penggunaan ra'yu secara bebas tanpa mengaitkannya kepada naș. Di manakah posisi kias dalam Hukum Pidana Islam, masih berkaitan dengan naș sebagai teks keagamaan atau sama sekali telah jauh dari rumusan teks suci dalam al-Qur'an dan hadis Nabi?. Bolehkah penetapan sanksi dalah Hukum Pidana Islam keluar dari konteks asas legalitas yang berlaku dalam hukum pidana positif? Sebelum hal ini dibahas, dalam tulisan ini terlebih dahulu akan penulis paparkan mengenai pengertian kias dalam hukum Islam.

\section{B. Pengertian Kias dalam Hukum Islam}

Secara etimologis kias berasal dari kata "قاس - يقيس - قياسا yang berarti mengukur, membandingkan dan mempersamakan. ${ }^{1}$ Dalam al-Mu'jam alWasit disebutkan bahwa secara bahasa kias berarti "ردالشى الى نظيره mengembalikan sesuatu dengan bandingannya, ${ }^{2}$ maksudnya mengukurnya. Al-Jurjāni mengatakan bahwa arti kias secara bahasa adalah :

عبا رة عن التقدير يقال : قست النعل بالنعل إذاقدرته وسويثه وهو عبارة عن ردالشىء إلى نظيرهُ "Pernyataan dari sebuah ukuran, misalnya ada seseorang yang mengatakan aku mengukur sandal dengan sandal, maksudnya mengukur dan menyamakan sandal tersebut. Kata kias mempunyai arti mengembalikan atau mengukur sesuatu dengan bandingannya."

Para penulis buku ushul fikih, ketika memberikan definisi kias secara etimologis beragam pernyataan yang mereka kemukakan. 'Abdu al-Wahhab
Khalāf mengatakan :

$$
\text { يماثله تسوية بينهما4 التسوية لأن تقديرالثىء بما }
$$

"Makna kias secara luas berarti persamaan, karena mengukur sesuatu dengan yang sepadannya berarti mempersamakan antara keduanya."

Hampir sama dengan apa yang dikemukakan 'Abdu al-Wahhab Khallāf, al-Syawkānì mengatakan :

$$
\text { وتسويته اللغة تقدير شى على مثال شى أخر }
$$

"Kias secara bahasa adalah mengukur sesuatu atas misal sesuatu yang lain dan mempersamakannya”.

Sementara itu 'Abdul Karim Zaidān mengemukakan :

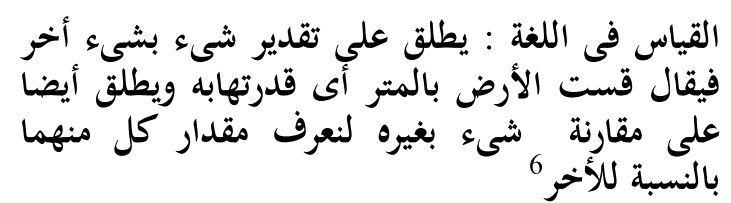

"Kias secara bahasa, secara luas berarti mengukur sesuatu dengan sesuatu yang lain, kalau ada orang berkata : "saya mengukur tanah meteran" maksudnya adalah aku mengukur luas tanah tersebut dengan alat meteran. Kias secara luas juga berarti membandingkan sesuatu dengan benda lain, agar kita mengerti ukuran masing-masing dibandingkan dengan yang lain".

Secara agak lengkap Wahbah alZuhayli memberikan penjelasan tentang arti kias secara etimologis sebagai berikut

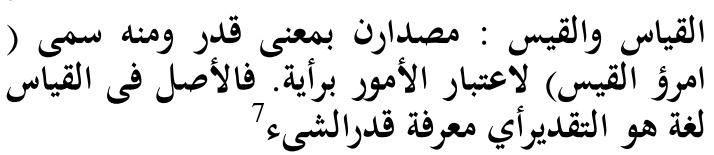

"Kias dan Qais: keduanya berbentuk verbal noun/infinitive yang berarti mengukur. Dari sinilah ada orang dinamakan Amrul Qais, karena sering banyak hal yang dipertimbangkan menurut pendapat Amrul Qais tersebut. Pada dasarnya secara bahasa Kias berarti ukuran, yaitu untuk mengetahui ukuran sesuatu”. 
Terakhir, tinjauan etimologis terhadap kata kias ini disampaikan oleh penulis kamus klasik, al-Fayyumi dalam al-Misbāh al-Munir-nya menjelaskan ketika kata "قاس - يقوس sebagaimana kata kerja " قتتل - قيقتل "قئل dan bentuk verbal nounnya adalah " قياس" maka artinya adalah " المقدار": " المقيا " ykuran.8

Dari penjelasan ahli bahasa dan para penulis tentang arti kata kias secara etimologis seperti uraian di atas, dapat disimpulkan bahwa secara etimologis kias berarti mengukur, mempersamakan dan memperbandingkan antara suatu benda atau suatu hal kepada benda lain atau hal yang lain karena terdapat unsurunsur persamaan antara keduanya. Itulah arti kata kias secara bahasa.

Adapun definisi kias secara terminologis dapat dikemukakan sebagai berikut :

1. Kias menurut tim penyusun kamus al-Mu'jam al-wasit adalah :

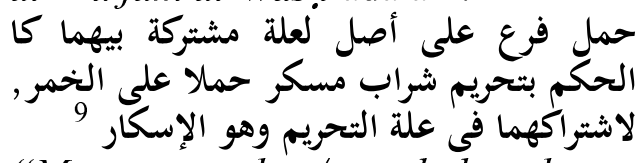

"Menanggungkan/menghubungkan suatu cabang kepada suatu asal karena ada persamaan 'illat ${ }^{10}$ antara cabang dan asal tersebut. Seperti menggabungkan semua jenis minuman yang memabukkan kepada khamr, karena ada unsur kesamaan antara senua jenis minuman tersebut dengan khamr dalam hal adanya 'illat hukum haram, yaitu sifat memabukkan".

2. Kias menurut Imam al-Ghazali dalam al-Mustașfä adalah :

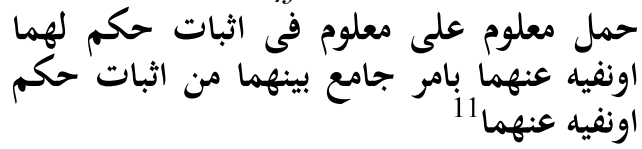

"Menanggungkan/menghubungkan sesuatu yang diketahui dalam hal ini menetapkan hukum pada keduanya atau meniadakan hukum dari keduanya disebabkan ada hal yang sama antara keduanya, dalam menetapkan hukum atau peniadaan hukum".

3. Sangat mirip dengan definisi kias alGhazali, al-Syawkāni mengemukakan definisi kias dengan

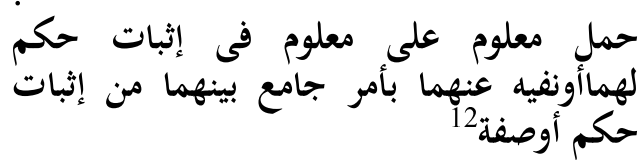
"Menanggungkan/menghubungkan sesuatu yang diketahui kepada sesuatu yang diketahui dalam hal menetapkan hukum pada keduanya atau meniadakan hukum dari keduanya disebabkan ada hal yang sama antara keduanya dalam menetapkan hukum atas sifat".

4. Menurut 'Abd al-Wahhāb Khallāa, kias adalah :

إلحاق واقعة لانص على حكمها بواقعة ورد نص الحص

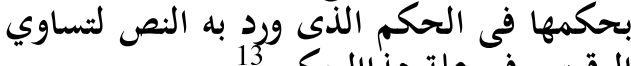
الوقعتين في علة هذاוالحكم. "Menghubungkan kejadian/peristiwa yang tidak ada naș tentang hukumnya dengan kejadian/peristiwa yang terdapat naș tentang hukumnya sesuai dengan hukum yang terkandung di dalam naș karena adanya persamaan 'illat hukum antara dua kejadian/peristiwa tersebut".

5. Abū Zahrah, mengutip lima definisi kias yang telah dikemukakan oleh para ahli yaitu al-Ghazāil, alBaidāwì, Sadru al-Syari'ah, Ibn alHājib dan Ibn al Hammām. ${ }^{14}$

Dari lima defininisi kias secara terminologis di atas, empat di antaranya menggunakan kata "مل", menanggungkan atau menghubungkan. Ada yang menggabungkan dengan kata "فرع dan " cabang dan asal dan ada yang menggabungkan dengan kata "معلم" dan "معلوم" sesuatu yang 
diketahui dan sesuatu yang diketahui. Tentu saja definisi terminologis yang menggunakan kata fur '́ ' dan asal akan lebih mudah difahami daripada yang menggunakan kata "sesuatu yang diketahui" dan "sesuatu yang diketahui". Sebab rukun kias yang meliputi asal, furū', hukum asal dan hukum furū' serta 'illat hukum jelas lebih popular di kalangan para pemerhati ilmu ushul fikih. Di antara kelima definisi kias tersebut satu di antaranya telah dikemukakan di atas, yaitu definisi kias yang dikemukakan oleh Imam al-Ghazāli, Selanjutnya akan dikemukakan beberapa difinisi kias secara berurutan di bawah ini yaitu :

a. Kias menurut al-Bayḍ̄â̄i adalah:

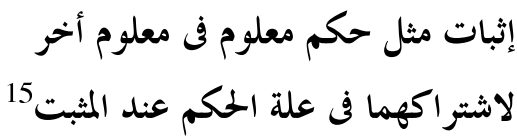

"Menetapkan semisal hukum yang diketahui pada sesuatu yang diketahui karena keduanya berasamaan dalam 'illat hukum menurut pandangan ulama yang menetapkan”.

b. Kias menurut Șadr al-Syari'ah adalah :

$$
\text { تعديةحكم من الا صل إلى الفرع بعلة }
$$

“Merentangkan/menjangkaukan hukum dari asal kepada asal karena ada kesatuan 'illat yang tidak mungkin dikenal dengan pemahaman bahasa semata”.

c. Kias menurut Ibn al-Hāāib adalah :

$$
\text { مساواة الفرع الأصل فى علة حكمه }
$$

"Samanya furu' dengan asal dalam 'illat hukumnya. Ulama
al-Musawwib menambahkan terhadap definisi ini kata "menurut pandangan orang yang menetapkan".

d. Kias menurut Ibn al-Hammām adalah :

$$
\text { لا تدرك بمجرود اللغة محلّ لأخر في علة حكمه له شرعي : }
$$

"Samanya suatu wadah (tempat berlakunya hukum) dengan yang lain dalam 'illat hukumnya. Baginya terdapat artian syar'i yang tidak dapat dipahami dari segi kebahasaan".

6. Menurut 'Abd al-Karīm Zaydān, kias adalah :

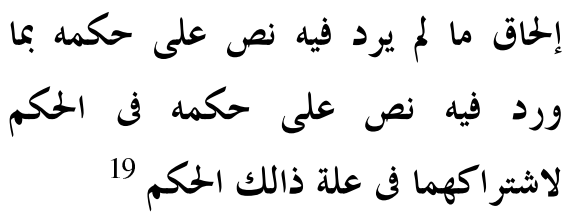

"Menghubungkan sesuatu yang tidak terdapat ketetapan nas tentang hukumnya dengan sesuatu yang di dalamnya terdapat ketetapan nas tentang hukumnya agar memperoleh ketetapan hukum karena adanya bersama dalam 'illat hukumnya”.

7. Menurut Wahbah al-Zuhayli kias adalah :

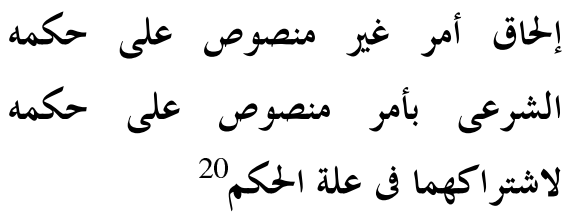

"Menghubungkan suatu persoalan yang tidak ada nas atas hukum syara'nya dengan suatu persoalan yang telah terdapat nas atas hukumnya karena keduanya bersama dalam 'illat hukumnya).

8. Menurut Badrān Abu al'Aynayn Badrān, kias adalah : 


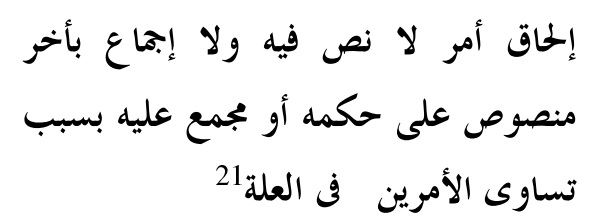

"Menghubungkan suatu persoalan yang tidak ada nas dan kesepakatannya dengan persoalan lain yang ada nas hukumnya atau ada kesepakatannya dengan sebab adanya persamaan 'illat hukum dua persoalan tersebut".

9. Menurut Ibnu al-Subki dalam Jam' al-Jawāmi', kias adalah :

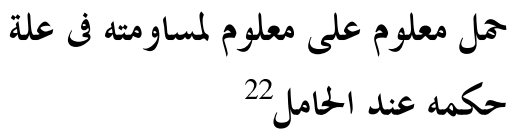

"Menghubungkan sesuatu yang diketahui kepada yang diketahui kerena kesamaannya dalam illat hukumnya menurut pihak yang menghubungkan/mujtahid".

10. Menurut Syarafuddin Yahyā al'Imrițĩ dalam Tashilu al-Turuqāt Linazmi al-Waraqāt, mendefinisikan kias dalam bentuk nazam sebagai berikut :

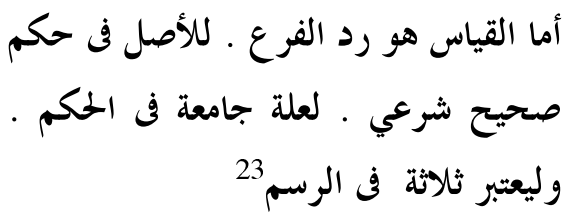

"Kias adalah mengembalikan cabang kepada asal dari segi hukum syara' yang benar karena adanya 'illat yang bersama dalam hukum, pelajarilah ketiga bentuk-bentuk kias".

Dari sembilan buah definisi kias di atas, ada yang menggunakan kata "إنبات" menetapkan, ada yang menggunakan kata "تعدية" merentangkan/ menjangkaukan, ada yang memakai kata "مساواة" samanya atau persamaan, ada pula yang memakai kata "لحاق" menghubungkan, ada yang lebih cenderung kepada kata "مل" menanggungkan atau menghubungkan dan yang paling terakhir al-Zuhayli menggunakan kata " 2, mengembalikan, sebagaimana makna etimologisnya. Semua definisi kias ini selalu menekankan tentang adanya 'illat, asal, furu', hukum asal dan sesuatu yang dihasilkan yaitu hukum furu' ${ }^{\prime}$. Inilah hasil dari sebuah upaya analogi dalam hukum Islam. Dengan demikian, dapat disimpulkan bahwa kias adalah sebuah upaya untuk menyamakan atau menganalogikan suatu hal, atau suatu persoalan atau suatu peristiwa dan kasus tertentu yang tidak terdapat ketentuan tegasnya dalam naṣ-naș baik alQur'an maupun hadis, dengan suatu hal atau suatu persoalan atau suatu peristiwa dan kasus yang telah terdapat ketetapan nas pastinya baik dalam alQur'an maupun dalam hadis. Upaya analogi ini bisa dilakukan sebab antara persoalan yang sudah ada nas-nya dan persoalan yang belum ada nasnya itu terdapat kesamaan 'illat, alasannya adalah agar persoalan pertama yang belum ada nas-nya dapat memperoleh status hukum sebagaimana persoalan kedua yang telah ada naș hukumnya secara tegas dan jelas.

Contoh yang paling populer tentang kias ini adalah mengkiaskan narkoba dengan khamr, narkoba yang tidak ada nasnya bisa dan memungkinan untuk dikiaskan dengan khamr yang telah ada nasnya karena 'illat atau alasan logis yang ada dalam zat narkoba dan khamr dinilai sama, yaitu sama-sama 
memabukkan. Dalam kasus ini terdapat upaya menetapkan suatu status hukum, yaitu status hukum narkoba sama dengan status hukum khamr. Contoh lain yang bisa dikemukakan di sini adalah tentang mengkiaskan berbagai macam kegiatan atau rutinitas keseharian dengan jual beli. Berbagai kegiatan atas rutinitas keseharian pada saat azan jumat berkumandang yang memang tidak terdapat nasnya dikiaskan dengan jual beli ( البيع) yang jelas sudah ada nașnya. ${ }^{24}$ Karena 'illat antara berbagai macam kegiatan dan rutinitas keseharian dan jual beli dianggap sama, yaitu sama-sama merupakan kesibukan yang akan memalingkan para pelaku dari shalat jum'at. Memang pada contoh yang kedua ini lebih pada menetapkan suatu hukum, bukan memasukkan suatu perbuatan sebagai perbuatan jarimah. Namun demikian, terkait contoh pertama tentang narkoba dikiaskan dengan khamr, tampaknya sudah sangat jelas dari sisi rukun dan komponen-komponen pokok terkait kajian tentang kias ini.

Selanjutnya bisa penulis tegaskan di sini bahwa dengan mempertimbangkan tingkat bahaya dan efek negatif narkoba yang bisa jadi lebih besar daripada sekedar khamr, maka pelaku jarimah terkait kasus narkoba dapat dituntut dengan hukuman hudūd dan sekaligus ta'zir. Misalnya bagi pihak pemakai cukup dihukum cambuk sebanyak 40 kali sebagai hudūd, sedangkan bagi pihak pengedar, selain dapat dikenai hukuman cambuk 40 kali juga dapat dituntut dengan jenis hukuman lain seperti dipenjara atau didenda. Bahkan bagi pihak yang memproduksi, memakai dan mengedarkan bisa dituntut dengan hukuman mati sebagai ta'zir. Dalam hal ini penulis berpendapat bahwa sanksi hukuman ta'zir tidak selalu harus lebih

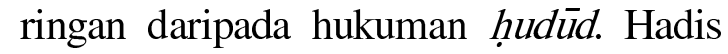
من بلغ حدا في غير حد " yang menyatakan bahwa "فهو من المعتدين "barang siapa yang melampaui hukuman had, padahal tidak termasuk ḥudūd berarti ia telah melampaui batas, lebih penulis pahami bahwa barang siapa menetapkan hukuman tidak sesuai dengan tingkat kejahatan yang dilakukan oleh pelaku, maka ia jelas telah melampaui batas. Dengan kata lain, hukuman ta'zir harus proporsional sesuai dengan tindak pidana yang dilakukannya, tidak boleh terlalu keras, tetapi tetap harus tegas dan jangan lembek.

Contoh lain terkait urgensi kias dalam hukum pidana Islam ini adalah dalam menetapkan hukuman bagi pelaku tindak pidana korupsi. Korupsi dapat dikiaskan dengan jarimah sariqah atau pencurian. Namun mengingat tingkat bahaya dan efek negatif korupsi ini jauh lebih besar daripada sekedar mencuri, maka menurut hukum pidana Islam, seorang koruptor dapat dituntut dengan sanksi hudüd dan sekaligus ta'Zïr. Memang dalam hal contoh yang terakhir ini masih menjadi perbincangan di kalangan para ahli dan pemerhati berbagai jarimah kontemporer saat ini seperti korupsi. Bila melihat konsep asas legalitas dalam hukum pidana, maka tidak boleh menganalogikan korupsi dengan mencuri, tetapi bila mengacu pada konsep kias dalam hukum Islam, maka sangat memungkinkan proses analogi korupsi dengan mencuri.

\section{Perdebatan Seputar Boleh dan Tidaknya Analogi dalam Bidang Hudud}

Dengan adanya asas legalitas dalam hukum pidana dan larangan analogi atau kias dalam menentukan pidana sebagaimana dikemukakan oleh para pakar Pidana seperti Moeljatno dan Andi Hamzah, maka tindak pidana korupsi misalnya tidak bisa dianalogikan, dikiaskan atau dianggap sama dengan delik pencurian. Alasannya adalah asas legalitas dan larangan analogi dalam hukum pidana.

Asas legalitas yang tercantum dalam pasal 1 ayat 1 KUHP berasal dari seorang sarjana berkebangsaan Jerman, 
Feurbach (1775-1833). Dengan rumusan yang sangat populer berbahasa latin "Nullum delictum nulla poena sine praevia legi poenali," yang dapat diartikan ke dalam bahasa Indonesia kata demi kata dengan, tidak ada delik, tidak ada pidana tanpa ketentuan pidana yang mendahuluinya. ${ }^{25}$ Di antara tiga pengertian dasar sebagai penjabaran dari asas legalitas di atas, Moeljatno dan Andi Hamzah menyebutkan bahwa untuk menentukan adanya perbuatan pidana tidak boleh digunakan analogi (kias). ${ }^{26}$

Dalam masalah analogi atau kias dalam bidang hudud ini tampaknya memang menjadi bahan perdebatan dan diskusi panjang di antara para tokoh hukum pidana sejak dulu, ada yang menerima analogi dalam bidang pidana atau hudud dan ada pula yang menolak. Kelompok penerima di antaranya Taverne, Pompe, dan Jonkers. Kelompok penentang di antaranya Scholten, van Hantum, termasuk yuris sekarang Jan Remmelink. Yuris atau ahli hukum pidana Indonesia sebagian besar menentang penerapan analogi dalam bidang pidana, di antaranya Moeljatno, Roeslan Saleh dan Andi Hamzah.

Untuk pakar pidana yang disebutkan terakhir ini bahkan secara tegas menolak kesimpulan dan penemuan penulis dalam disertasi yang berjudul Tindak Pidana Korupsi di Indonesia dalam Perspektif Fikih Jinayah. Pada awalnya penulis kemukakan dalam ujian pendahuluan disertasi di Sekolah Pascasarjana UIN Syarif Hidayatullah Jakarta pada hari Rabu tanggal 14 Mei 2008 bahwa tindak pidana korupsi di Indonesia menurut fikih jinayah atau hukum pidana Islam masuk dalam kategori jarimah hudīd, karena tindak pidana korupsi sama dengan tindak pidana pencurian, hanya modus operandinya yang berbeda, intinya samasama mengambil hak orang lain baik milik perseorangan maupun milik Negara.
Pendapat penulis inilah yang sangat tidak disetujui oleh Andi Hamzah. Atas saran dan masukan berbagai pihak, dan tentunya dengan mempertimbangkan kepakaran dan kapasitas Andi Hamzah sebagai pakar pidana Indonesia saat ini, maka dalam ujian promosi doktor pada hari Senin tanggal 7 Juli 2008 yang pada saat itu tidak dihadiri oleh Andi Hamzah, penulis merubah pendirian bahwa tindak pidana korupsi menurut hukum pidana Islam masuk dalam ranah jarimah ta'zir bukan jarimah hudüd. ${ }^{27}$ Alasannya adalah karena dalam pidana tidak diperbolehkan menggunakan analogi. Sehingga dengan memasukkan tindak pidana korupsi ke dalam kategori jarimah ta'zir analogi dalam pidana bisa dihindari yaitu tidak menganalogikan korupsi dengan mencuri.

Tindak pidana korupsi tidak sama dengan mencuri, sebab unsur-unsur korupsi memang berbeda dengan unsurunsur mencuri. Perbedaan mendasarnya terletak pada konsep kepemilikan dan kekuasaan pelaku kedua jenis delik ini. Kalau mencuri, tidak ada hubungan antara kekuasaan, kewenangan atau kepemilikan pelaku atas harta yang dicurinya. Sebab harta itu ada di bawah kekuasaan dan kewenangan pihak lain dan tidak ada keterkaitan dengan posisi dan jabatan pencuri tersebut. Sedangkan pada tindak pidana korupsi, terdapat keterkaitan erat antara kedudukan, posisi dan jabatan pelaku korupsi dengan harta yang dikorupsinya, bahkan sangat bisa jadi, pada harta yang dikorupsinya terdapat bagian tertentu, walaupun sangat kecil kepemilikan pelaku atas harta yang dikorupsinya, sehingga ia merasa berhak atas harta yang dikorupsiunya.

Oleh karena dalam tindak pidana korupsi ada kemungkinan terdapat bagian kepemilikan harta bagi pelaku korupsi atas harta yang dikorupnya, maka dalam kondisi seperti ini jelas terdapat unsur syubhat, yaitu syubhat kepemilikan. Contoh klasik dalam berbagi literatur fikih mengenai syubhat yang berkaitan 
dengan unsur kepemilikan ini adalah seorang ayah yang menggauli budak milik anaknya harus dibebaskan dari tuntutan pidana. Alasannya adalah karena di dalamnya terdapat unsur syubhat berupa syubhat kepemilikan. Demikian halnya dalam tindak pidana korupsi terdapat unsur syubhat kepemilikan. Pada saat terdapat unsur syubhat, maka hukuman atau sanksi pidana harus dihindari. Oleh sebab itu tindak pidana korupsi tidak bisa dimasukkan ke dalam ranah jarimah hud $\bar{u} d$, melainkan jarimah ta'zir, yaitu jenis jarimah yang tidak secara langsung diatur dalam al-Qur'an dan hadis, melainkan sebagai kebijakan hukum penguasa sebuah negara setempat.

Menurut penulis, perdebatan tentang apakah tindak pidana korupsi masuk ke dalam ranah jarimah hudid atau ta'zir sudah selesai dan tuntas sampai di sini. Jika sekiranya masih ada pihak yang tidak setuju bahwa korupsi masuk dalam kelompok jarimah ta'zir, dengan alasan bahwa kalau hanya ta'zir maka hukumannya sangat ringan karena tidak bisa melampaui sanksi pidana hud $\bar{u} d$ yang maksimal berupa 80 kali dera atau cambuk, maka penulis dapat memahami alur pemikiran ini, yakni karena orang yang berpendapat demikian ini hanya mengikuti pola pemikiran ulama kalangan Syafi'iyyah, bukan ulama dari kalangan mazhab Hanafi yang menyebutkan bahwa sanksi ta'zïr bisa saja lebih keras daripada sanksi hud $\overline{u d}$ bahkan bisa berupa hukuman mati.

Lebih jauh dari itu bahwa mengapa Andi Hamzah tidak setuju bahwa korupsi sama dengan mencuri?, alasannya karena asas legalitas yang akhirnya melahirkan doktrin tidak boleh ada analogi dalam pidana. Pada dasarnya pendirian seperti ini juga sangat debatable artinya masih manjadi perbincangan sengit di kalangan para ulama ushul fikih. Andi Hamzah pada saat meyakinkan penulis mengenai larangan analogi dalam hukum pidana, menyarankan agar penulis membaca buku
Crimes Againts Humanity in International Crimiminal Law tulisan M. Cherif Bassiouni, ahli hukum pidana Internasional berkebangsan Mesir.

Dalam bukunya, M. Cherif Bassiouni menyebutkan bahwa hud $\bar{u}$, crime which are codified in the Qur'an, require a rigid aplication of the principles of legality ${ }^{28}$, hudūd sebagai sebuah jarimah yang telah disebutkan secara tegas di dalam al-Qur'an harus dilaksanakan secara baku, tegas atau apa adanya sesuai dengan prinsip-prinsip keabsahan hukum. Dalam jarimah hudud tidak berlaku analogi, berbeda dengan qisas apalagi ta'zir, yang di dalamnya bisa berlaku analogi. ${ }^{29}$ Secara lebih tegas Andi Hamzah menyatakan bahwa hud $\bar{d} d$ is strictly not allowed analogy, hudìd bersifat kaku dan dilarang keras memakai analogi dalam hudud. ${ }^{30}$

Dalam kajian ushul fikih, persoalan analogi atau kias dalam masalah hudìd dan kifarat merupakan sebuah masalah yang menjadi bahan perdebatan panjang di kalangan para ulama ahli ushul fikih. Al-Amidi menyebut perbedaan pendapat dimaksud adalah Imam Syafi'i dan Ahmad bin Hanbal di satu pihak dan Abu Hanifah di pihak lain. Pihak pertama membolehkan analogi dalam bidang hud $\bar{u} d$ dan kafarat sedangkan pihak kedua melarang analogi dalam bidang $h u d \bar{u} d$ dan kafarat. ${ }^{31}$

Hampir dalam semua buku ushul fikih disebutkan seperti yang dikemukakan oleh al-Amidi di atas. Namun pada saat menyebut nama ulamanya mereka berbeda-beda. AlSyawkāni menyebut pihak pertama dengan sebutan ghayruhum, yaitu para ulama di luar kalangan Hanafiah dan menyebut pihak kedua dengan sebutan Hanafiah. $^{32}$ Imam al-Ghazali tidak menyebutkan nama para pihak, baik pihak pertama maupun kedua, tetapi materi perdebatannya ia paparkan secara mendetail. ${ }^{33}$

Hal serupa juga dilakukan oleh 'Abd al-Mu`min al-Hanbali, ${ }^{34}$ Abū 
Zahrah $^{35}$ dan Badrān Abū al-'Aynayn Badran $^{36}$ menyebut pihak pertama dengan sebutan ulama Syafi'iyah sementara untuk pihak kedua dengan sebutan Hanafiah.

\section{Larangan Analogi dalam Bidang Hud üd Sebagai Sebuah Bentuk Kejumudan Hukum Pidana Islam}

hukum pidana dibayangkan jika memperbolehkan analogi dan kias sebagai sumber keempat hukum pidana Islam harus dihapuskan. Dalam masalah ini penulis berpendapat bahwa hukum Pidana Islam memiliki spesifikasi dan ciri khusus yang tidak bisa disamakan begitu saja dengan hukum pidana konvensional atau hukum pidana positif. Banyak hal yang perlu dibahas dan dipertimbangkan kalau antara hukum pidana positif dan hukum pidana Islam harus disamakan.

Antara hukum pidana Islam dan hukum pidana positif hanya bisa diperbandingkan dan disandingkan tetapi tidak bisa disamakan. Inilah asumsi atau kesimpulan sementara penulis. Antara keduanya memang banyak hal yang sama namun lebih banyak yang berbeda. Contoh konkrit berkaitan dengan pembahasan dalam tulisan ini adalah mengenai boleh dan tidaknya analogi dalam bidang pidana Islam.

Tampaknya dalam pidana positif analogi dilarang keras agar tidak terjadi kesemrawutan dan supaya tidak menimbulkan hal-hal yang bisa merugikan pihak terpidana, terlebih bila dihubungkan dengan asas legalitas dari hukum pidana positif. Namun dalam hukum pidana Islam kalau analogi juga harus dilarang, menurut penulis justru akan mengakibatkan mandeg dan jumudnya hukum pidana Islam itu sendiri. Bahkan sangat dimungkinkan akan terjadi ketidakadilan dan kesimpangsiuran dalam penerapan hukum.

Dalam hal korupsi tidak sama atau berbeda dengan mencuri memang sangat sejalan antara hukum pidana positif dengan hukum pidana Islam, sebab unsur-unsur pidana antara keduanya memang berbeda sebagaimana penulis kemukakan pada uraian sebelumnya. ${ }^{37}$ Tetapi dalam hal-hal lain seperti larangan menganalogikan narkoba dengan khamr justru akan berakibat fatal. Sebab kalau narkoba tidak masuk dalam kategori khamr yang secara tegas disebutkan oleh al-Qur'an, maka para pemakai, pengedar dan bahkan produsen heroin, putaw, ekstasi, inek, magadon, bir, topi miring dan sejumlah nama narkoba lain akan terbebas dari tuntutan pidana. Oleh sebab itu analogi dalam hukum pidana Islam tetap harus dipertahankan. Sehingga eksistensi kias sebagai sumber hukum pidana Islam yang keempat tetap harus dipertahankan.

Dengan adanya kias sebagai sumber hukum pidana Islam, maka segala macam tindak pidana kontemporer yang tidak disebutkan secara tekstual dalam alQur'an dan hadis tetap bisa dituntut sanksi pidananya. Tindak pidana korupsi, money loundering, illegal logging, women travicking, baby travicking, cyber crime, penyebaran vcd porno, merekam adegan perzinaan dan diketahui atau dipublikasikan kepada masyarakat melalui berbagai alat dan media-media lain harus tetap bisa dituntut secara pidana, terlebih secara pidana Islam.

Perlu penulis kemukakan di sini bahwa pengkiasan narkoba dengan khamr dan korupsi dengan sariqah atau mencuri terbatas pada penetapan status hukum keharaman atas kedua jarimah tersebut, tidak sampai pada penetapan sanksi dan bentuk-bentuk hukumannya. Narkoba hukumnya haram sama dengan khamr tindak pidana korupsi juga haram sama dengan mencuri. Akan tetapi terkait dengan bentuk hukuman atas kasus jarimah narkoba dan korupsi tidak harus sama persis dengan bentuk hukuman atas khamr dan sariqah. Hal ini penting untuk ditegaskan, sebab sangat bisa jadi bahaya dan afek negatif narkoba dan korupsi 
akan jauh lebih besar daripada sekedar khamr dan mencuri. Oleh sebab itu pelaku kedua jenis jarimah ini dapat dituntut dengan hukuman hud $\bar{u} d$ dan sekaligus ta'zir. Jadi seorang produsen narkoba bisa dihukum cambuk sebanyak 40 kali sebagai hud $\bar{u} d$ lalu dihukum mati sebagai ta'zir. Demikian halnya seorang koruptor, terlebih jika ia melakukan tindak pidana korupsinya dalam keadaan tertentu, sebagaimana disebutkan dalam pasal 2 ayat (2) UU No 31 tahun 1999 jo UU no 20 tahun 2001 tentang pemberantasan tindak pidana korupsi, dikenai sanksi pidana mati sebagai ta'zirr, setelah terlebih dahulu dikenai sanksi potong tangan layaknya seorang pencuri.

\section{E. Penutup}

Penulis akan mengakhiri tulisan ini dengan pernyataan bahwa kias adalah sebagai sumber hukum pidana Islam yang keempat. Adapun sumber hukum Pidana yang pertama, kedua dan ketiga secara berurutan adalah al-Qur'an, hadis dan ijmak. Jadi sumber hukum pidana Islam sama dengan sumber hukum Islam pada umumnya, yaitu al-Qur'an, hadis, ijmak dan kias. Pada sumber keempat inilah perbedaan dan perdebatan panjang para ulama terjadi. Sebagai cacatan akhir penulis kemukakan bahwa sebuah jarimah bisa dikategorikan menjadi jarimah ta'zir jika ia tidak masuk ke dalam kelompok jarimah qisas dan hudūd. Sebab qisas hanya meliputi dua macam, penganiayaan dan pembunuhan, kemudian hudüd meliputi tujuh macam delik yakni zina, menuduh zina meminum khamr, mencuri, merampok, memberontak dan murtad. Di luar jenisjenis jarimah di atas, pasti masuk dalam kelompok jarimah ta'zir. Dengan demikian jarimah ta'zir sangat luas dan tidak terbatas. Oleh sebab itu berbagai jenis tindak pidana kontemporer pasti masuk ke dalam ranah jarimah ta'zir. Adapun pemberlakuan dan jenis-jenis jarimah ta'zir sepenuhnya diserahkan kepada penguasa dan hakim setempat.
Untuk konteks Indonesia, KUHP pada dasarnya merupakan jenis atau bentuk sanksi ta'zir. Namun karena Indonesia tidak menjadikan al-Qur'an dan hadis sebagai dasar hukumnya, Indonesia juga bukan merupakan negara Islam, walaupun mayoritas penduduknya beragama Islam, maka untuk langsung mengatakan bahwa KUHP adalah bentuk ta'zir ala Indonesia tidak sepenuhnya bisa disepakati oleh para ahli. Azyumardi misalnya, menurutnya hukuman ta'zir hanya bisa berlaku, kalau negara tersebut bisa disebut sebagai negara Islam, yaitu negara yang dipimpin oleh seorang amir atau khalifah. Indonesia, walaupun mayoritas penduduknya beragama Islam, tetap tidak bisa disebut sebagai negara Islam. Untuk bisa memberlakukan hukuman ta'zir perlu adanya landasan atau dalil fikih yang memadai.

Menurut Azyumardi, dalil fikih yang bisa dikemukakan adalah bahwa tahun 1954, alim ulama NU dalam konferensi tanggal 2-7 Maret 1954 di Cipanas memberikan gelar waliyy al-amr al-darüri bi al-syawkah kepada Presiden Soekarno sebagai Presiden Republik Indonesia. $^{38}$ Penjelasannya bahwa oleh karena negara Indonesia bukan negara Islam, tetapi mayoritas penduduknya beragama Islam maka dalam kerangka fikih siyasah secara "darurat" harus ada waliyy al-amr yang sudah memiliki syaukah, kewenangan atau otoritas. Dengan diberikan gelar ini, Soekarno sebagai presiden secara implisit adalah seorang amir yang telah mendapatkan tawliyyah atau pelimpahan sebagai waliyy al-amr al-daruri bi al-syawkah. Kalau presiden, aparat negara dan para penegak hukum di Indonesia sudah berkedudukan sebagai waliyy al-amr al-darürí bi alsyawkah, maka mereka memiliki wewenang untuk mengatur dan melaksanakan hukuman-hukuman ta'zir sebagaimana ditetapkan dalam fikih jinayah. 


\section{Catatan Akhir}

1 Ahmad Warson Munawir, Kamus AlMunawwir, cet. 14 (Surabaya: Pustaka Progressif, 1997), hlm. 1177.

2 Ibrahim Anis, dkk, al-Mu'jam alWasịt, cet. 2 (Mesir: Majma' al-Lughah alArabiyyah, 1972), hlm. 770.

${ }^{3}$ Ali bin Muhammad al-Jurjani, Kitāb al-Ta'rifät (Jakarta: Dār al-Hikmah, t.t.), hlm. 79.

4 'Abd al-Wahhab Khalāf, 'Ilmu UsūlalFiqh, (Al-Qāhirah: Dār al-Hadis, 2003), hlm 59.

${ }^{5}$ Muhammad ibn 'Ali ibn Muhammad Al-Syawkāni, Irsyād al-Fuhūl, cet. 1 (Makkah: Al-Maktabah at-Tijariyyah, 1993), hlm. 337.

6 'Abd al-Karim Zaidan, al-Wajiz, fi Usūl al-Fiqh (Beirut: Mu`assasah al-Risālah, 1985), hlm. 194.

7 Wahbah al-Zuhayli, al-Fiqh al-Islami wa Adillatuh, cet. 4 ( Beirut: Dār al-Fikr alMa'āsir, 1997), I: 601.

8 Ahmad ibn Muhammad ibn 'Ali alMaqri al-Fayyūmi, al-Misbāh al-Munïr (Beirut: Dār al-Kutub al-'Ilmiyyah, tth), hlm. 521.

${ }^{9}$ Ibrahim Anis, dkk, al-Mu'jam al-Wasit, cet. 2 (Mesir: Majma' al-Lughah al-Arabiyyah, 1972), hlm . 770.

10 'illat adalah suatu sifat yang berfungsi sebagai pengenal bagi suatu hukum. Apabila terdapat suatu 'illat pada suatu kasus, maka hukumpun ada. Kata "sifat pengenal" dalam pengertian ini maksudnya adalah sebagai tanda atau indikasi keberadaan suatu hukum, bukan hukum, misalnya dalam definisi di atas sifat memabukkan merupakan 'illat dalam minuman khamr dan memabukan itu merupakan tanda atau indikasi atau penyebab adanya suatu hukum, yaitu keharaman minuman khamr, lihat Tim Penyusun, Ensiklopedi Hukum Islam, cet. 1 (Jakarta: Ichtiar Baru Van Hoeve, 1997), II: 698.

11 Abū Hāmid Muhammad ibn Muhammad bin Muhammad al-Ghazāil, alMustasfã min 'Ilm al-Usūl (Beirut: Dār a-Kutub al-Ilmiyyah : 1996), hlm. 280.

${ }_{12}$ Al-Syawkāni, Irsyād al-Fuḥūl, cet. 1

(Makkah: Al-Maktabah at-Tijāriyyah, 1993), hlm. 337.

${ }^{13}$ Abdu al-Wahhab Khalāf, 'Ilmu, hlm. 59.

14 Muhammad Abū Zahrah, al-Jarimah wa al-'Uqūbah fi al-Fiqh al-Islämī (Al-Qähirah: Dar al-Fikr al-Arabi, 1998), hlm. 288-289.

${ }^{15}$ Ibid.; lihat juga Amir Syarifuddin, Ushul Fiqih, cet. 2 (Jakarta: Logos, 2000), I: 146.

16 Abū Zahrah, al-Jarimah, hlm. 288289.

17 Ibid., hlm. 289, lihat juga Amir Syarifuddin, Ushul Fiqih, I: 146.
${ }^{18}$ Abū Zahrah, al-Jarimah, hlm 288-289

${ }^{19}$ Zaydān, al-WajīZ, hlm. 94.

${ }^{20}$ Al-Zuhayli, al-Fiqh al-Islāmī, I: 603.

${ }^{21}$ Badrān Abul Aynayn Badran, Tarikh al-Fiqh al-Islamī (Beirut: Dār al-Nahḍah alArabiyyah, t.t.), hlm. 203.

${ }^{22}$ Tāj al-Dīn 'Abd al-Wahhāb ibn alSubkì, Jam'u al-Jawāmi (Semarang: Toha Putera, t.t.), II: 202.

${ }^{23}$ Syaraf al-Dīn Yahyā al-'Imritîi, Tashīl al-Turuqāt Linażm al-Waraqāt (Indonesia: Dāru Inyă al-Kutub al 'Arabiyyah, t.t.), hlm. 51-52.

${ }^{24}$ Nas dimaksud adalah:

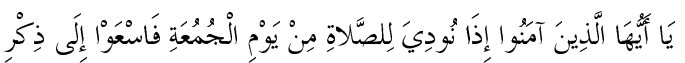

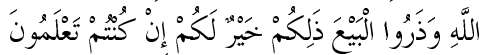

"Hai orang-orang beriman, apabila diseru untuk menunaikan shalat Jum'at, maka bersegeralah kamu kepada mengingat Allah dan tinggalkanlah jual beli. yang demikian itu lebih baik bagimu jika kamu mengetahui." Q.S. alJumu'ah (62) : 9.

25 Andi Hamzah, Asas-Asas Hukum Pidana, hlm 39-40.

${ }^{26}$ Ibid.

27 M. Nurul Irfan, Tindak Pidana Korupsi di Indonesia dalam Perspektif Fikih Jinayah, Cet. 1 (Jakarta: Badang Litbang dan Diklat Depag RI, 2009), hlm. 281.

${ }^{28}$ Ibid., hlm. 197.

${ }^{29}$ M. Cherif Bassiouni, Crimes Againts Humanity in International Crimiminal Law (Boston: t.n.p, 1999), hlm. 136.

30 Sebagaimana dinyatakan oleh Andi Hamzah pada Hari Rabu 14 Mei 2008 dalam ujian pendahuluan disertasi penulis.

${ }^{31}$ Sayf al-Dīn Abū al-Hasan 'Ali ibn Abì Ali ibn Muḥammad al-Āmidi, al-Ihkām fĩ Usūl al-Ahkām (Beirut:Dār al-Kutub al-Ilmiyyah, 1983), IV: 82.

32 Al-Syawkāni, Irsyād al-Fuḥūl, hlm. 377.

33 Al-Ghazā̄i, al-Mustaș $\overline{f a}$, hlm. 331.

34 'Abd al-Mu`min ibn 'Abd al-Haqu alBaghdādi al-Hanbali, Taisìr al-Wụsūl ilā Qawāid al-Usūl wa Ma'āqașid-al-Fusù̄l, cet. 2 (Al-Qāhirah: Dār ibn al-Jawżi, 1427 H.), hlm. 351.

${ }^{35} \mathrm{Abū}$ Zahrah, al-Jarimah, hlm. 141.

${ }^{36}$ Badrān, Tarikh al-Fiqh, hlm. 206.

37 Lebih jauh untuk mengetahui dan membandingkan unsur-unsur Tindak Pidana Korupsi dan konsep dasar fikih jinayah atau hukum Pidana Islam, lihat Irfan, Tindak Pidana, hlm. 171-262.

${ }^{38}$ Imam Ghazali Said (ed), Solusi Hukum Islam Keputusan Muktamar, Munas dan Konbes 
NU (1926-2004), cet. 3 (Surabaya: Diantama, 2006), hlm. 285 dan 644. Lihat Greg Fealy, Ijtihad Politik Ulama, Sejarah NU 1952-1967, cet. 1 (Yogyakarta: LkiS, 2003), hlm. 178-184. Lihat juga Mujar Ibnu Syarif, Presiden Non Muslim di Negara Muslim Tinjauan dari Perspektif Islam dan Relevansinya dalam Konteks Indonesia, cet. 1 (Jakarta: Pustaka Sinar Harapan, 2006), hlm. 3.

\section{DAFTAR PUSTAKA}

Al-Āmidi, Saifuddin Abū al-Hasan 'Ali ibn Abi Ali ibn Muhammad. alIṇkām fi Ușūl al-Aḥkām. Beirut: Dār al-Kutub al-Ilmiyyah, 1983.

Al-Baghdadi 'Abdul Mukmin ibn 'Abdul Haqq al-Hanbali. Taisir al-Wușūl ilä Qawäid al-Ușūl wa Ma'äqid al-Fusūul. al-Qāhirah: Dār Ibn alJauzi, $1427 \mathrm{H}$.

Al-Fayyūmì, Aḥmad ibn Muḥammad ibn 'Ali al-Maqrì. al-Misbāh alMunīr. Beirut: Dār al-Kutub al'Ilmiyyah, t.t.

Al-Ghazāî, Abū Hāamid Muḥammad ibn Muhammad ibn Muhammad. alMustasfá fi 'Ilm al-USūl. Beirut: Dar a-Kutub al-Ilmiyyah, 1996.

Al-'Imritīi, Syarafuddīn Yahyā. Tashīl alTuruqàt Linażm al-Waraqāt. Indonesia: Dāru Ihyā al-Kutub al 'Arabiyyah, t.t.

Al-Jurjani, Ali bin Muhammad. Kitāb alTa'rīfăt. Jakarta: Dār al-Hikmah, t.t.

Al-Subki, Tājuddin 'Abdu al-Wahhāb Ibn. Jam'u al-Jawāmi, 2 jilid. Semarang: Toha Putera, t.t.

Al-Syaukānì, Muhammad ibn 'Ali ibn Muhammad. Irsyād al-Fuhūl. Makkah: Al-Maktabah alTijariyyah, 1993.
Al-Zuhayli, Wahbah. al-Fiqh al-Islami wa Adillatuh. Beirut: Dār al-Fikr al-Ma'āsir, 1997.

Anis, Ibrahim dkk. al-Mu'jam al-Wasịt. Mesir: Majma' al-Lughah alArabiyyah, 1972.

Badrān, Abul Aynayn Badrān. Tarikh al-Fiqh al-Islami. Beirut: Dār alNahdah al-Arabiyyah, t.t.

Bassiouni, M. Cherif. Crimes Againts Humanity in International Criminal Law. Boston: T.n.p., 1999.

Hamzah, Andi. Asas-asas Hukum Pidana. Jakarta: Rineka Cipta, 1994.

Irfan, M. Nurul. Tindak Pidana Korupsi di Indonesia dalam Perspektif Fikih Jinayah. Jakarta: Badang Litbang dan Diklat Depag RI, 2009.

Khalāf, Abdu al-Wahhab. 'Ilmu Usūul alFiqh. al-Qāhirah: Dār al-Hadis, 2003.

Munawir, Ahmad Warson. Kamus AlMunawwir. Surabaya: Pustaka Progressif, 1997.

Syarifuddin, Amir. Ushul Fiqih, 2 jilid. Jakarta: Logos, 2000.

Tim Penyusun Departemen Agama. AlQur'an dan Terjemahnya. Surabaya: Mekar Surabaya, 2002.

Tim Penyusun. Ensiklopedi Hukum Islam, 6 jilid. Jakarta: Ichtiar Baru Van Hoeve, 1997.

Zahrah, Muhammad Abū. al-Jarimah wa al-'Uqübah fi Fiqh al-Islämī. al-Qahirah: Dar al-Fikr al-Arabi, 1998.

Zaidāan, 'Abdul Karim. al-Wajīz, fi Usūl al-Fiqh. Beirut: Mu'assasah alRisālah, 1985. 